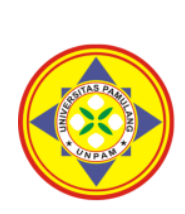
PERKUSS

\title{
PENGARUH RETURN ON ASSET DAN DEBT TO EQUITY RATIO TERHADAP EARNING PER SHARE PADA PT INDOSAT TBK PERIODE 2008-2019
}

\author{
1Polius Marselius Moho, ${ }^{2 *}$ Selby Virby \\ Universitas Pamulang, Tangerang Banten, Indonesia \\ shelby01364@unpam.ac.id
}

\begin{abstract}
Abstrak
Penelitian ini bertujuan untuk menguji secara empiris pengaruh variabel-variabel yang terdiri dari: Pengaruh Return On Asset dan Debt To Equity Ratio Terhadap Earning Per Share Pada PT Indosat Tbk Tahun2008-2019. Metode penelitian yang digunakan adalah metode kuantitatif dengan jenis penelitian metode deskriptif.Teknik analisis data pada penelitian ini dengan menggunakan uji statistik deskriptif, uji asumsi klasik, analisis linear berganda, Uji Determinasi dan uji hipotesis.Populasi yang digunakan pada penelitian ini PT Indosat Tbk Tahun 2008-2019.Sampel yang digunakan sebanyak 12 Tahun terakhir. Berdasarkaan hasil pengujian uji Fhitung yaitu 448,783 dan nilai signifikan 0,000<0,05, atau fhitung lebih besar dari Ftabel $(448,783>4,100)$ sehingga dapat disimpulkan bahwa Return On Asset dan Debt To Equity Ratio bersama-sama berpengaruh signifikan terhadap Earning Per Share.

Kata Kunci: Return On Asset, Debt To Equity Ratio, Earning Per Share
\end{abstract}

\section{Abstract}

This study aims to test empirically the influence of variables consisting of: The Effect of Return On Assets and Debt To Equity Ratio on Earning Per Share at PT Indosat Tbk in 2008-2019. The research method used is a quantitative method with descriptive method research type. The data analysis technique in this research is using descriptive statistical test, classical assumption test, multiple linear analysis, determination test and hypothesis testing. The population used in this study is PT Indosat Tbk in 2008-2019. The sample used was the last 12 years. Based on the results of the Fcount test is 448,783 and a significant value of $0,000<0.05$, or fcount is greater than Ftable $(448,783>4,100)$ so it can be concluded that the Return On Asset and Debt To Equity Ratio together have a significant effect. against Earning Per Share.

Keywords: Return On Asset, Debt To Equity Ratio, Earning Per Share

\section{PENDAHULUAN}

Bagi perusahaan yang telah go public atau menjadi perusahaan terbuka, maka tingkat profitabilitas yang baik akan menjadi nilai tambah tersendiri karena para calon investor atau para investor akan menjadikan tingkat profitabilitas tersebut acuan dan bahan pertimbangan, apakah mereka akan menambah atau mengurangi dana inventasi untuk perusahaan terbuka tersebut.

Mengenai laba atau profitabilitas perusahaan tidak terlepas dari pemanfaatan aset atau harta yang dimiliki perusahaan. Return On Asset (ROA) atau biasa disebut Tingkat Pengembalian Aset adalah rasio profitabilitas atau rasio yang mengukur seberapa efisien perusahaan dalam memanfaatkan atau mengelola asetnya untuk menghasilkan laba pada suatu periode tertentu. Biasanya ROA dinyatakan dalam bentuk persentase. ROA tidak hanya untuk manajemen saja tetapi juga investor, karena dari ROA dapat dilihat seberapa baik perusahaan mampu mengkonversi investasi pada aset menjadi laba atau imbal hasil investasi. Karena tentunya para investor ingin mendapat dividen yang besar. Untuk mendapat dividen yang besar, perusahaan harus memperoleh laba yang besar juga.

Jika Return On Asset dan Debt to Equity Ratio telah diperhitungkan maka selanjutnya adalah Earning Per Share (EPS) atau Laba Per Saham. Laba Per Saham adalah bagian dari laba perusahaan yang dialokasikan kesetiap saham yang beredar. Berikut ini disajikan hasil data olahan 
Perkembangan Rasio ROA, DER Dan EPS

pada PT Indosat Tbk Periode 2008-2019.

Dilihat pada tabel sebagai berikut:

Tabel 1. Perkembangan Rasio ROA, DER Dan EPS pada PT. INDOSAT Tbk Periode 2008-2019

\begin{tabular}{|c|c|c|c|c|}
\hline \multirow{2}{*}{ No } & \multirow{2}{*}{ Tahun } & ROA & DER & EPS \\
\cline { 3 - 5 } & & $(\%)$ & $(\%)$ & (Satuan Rupiah) \\
\hline 1 & 2008 & 3,63 & 19,53 & 3,46 \\
\hline 2 & 2009 & 2,72 & 20,47 & 2,76 \\
\hline 3 & 2010 & 1,37 & 18,96 & 1,33 \\
\hline 4 & 2011 & 1,79 & 17,73 & 1,72 \\
\hline 5 & 2012 & 0,98 & 17,94 & 1,01 \\
\hline 6 & 2013 & $-3,08$ & 21,02 & $-3,08$ \\
\hline 7 & 2014 & $-3,53$ & 27,26 & $-3,46$ \\
\hline 8 & 2015 & $-2,10$ & 31,76 & $-2,14$ \\
\hline 9 & 2016 & 2,51 & 25,86 & 2,35 \\
\hline 10 & 2017 & 2,57 & 24,19 & 2,41 \\
\hline 11 & 2018 & $-3,92$ & 33,79 & $-3,84$ \\
\hline 12 & 2019 & 2,60 & 35,82 & 3,01 \\
\hline
\end{tabular}

Data diolah penulis: $w$ ww.idx.co.id

Berdasarkan Berdasarkan data diatas pada tahun 2009 mengalami penururnan sebesar 2,72\% dari tahun sebelumnya bahkan mengalami kerugian sampai tahun 2015 mencapai -2,10. Pada tahun 2016 sampai 2017 mulai mengalami peningkatan sebesar 2,51\% ke 2,57\%, pada tahun 2018 kembali menurun senilai $-3,92 \%$. Namun tahun 2019 kembali meningkat yaitu 2,60\%. ROA tinggi artinya kemampuan perusahaan dalam menghasilkan laba semakin baik dan mampu meyakinkan investor untuk menanamkan sahamnya. Begitu juga dengan DER pada tahun 2015 meningkat menjadi $31,76 \% \%$ dibanding tahun sebelumnya. Namun pada tahun 2016 sampai 2017 terus menurun sebesar $25,86 \%$ ke 24,19\%. Tahun 2019 DER meningkat yaitu $35,82 \%$ yang artinya menunjukkan bahwa semakin tinggi angka DER maka perusahaan memiliki resiko terhadap likuiditas perusahaannya sehingga dapat mempengaruhi tingkat kemampuan perlembar saham dalam menghasilkan laba untuk perusahaan karena earning per share menjadi indikator keberhasilan perusahaan.

Berdasarkan latar belakang masalah pada perusahaan PT Indosat Tbk tersebut diatas, dimana perusahaan terus mengalami penurunan pendapatan atau penghasilan dan juga penurunan laba yang diperoleh perusahaan bahkan kerugian, maka penulis bermaksud mengadakan penelitian yang disusun dalam bentuk skripsi dengan judul: "Pengaruh Return On Asset dan Debt To Equity Ratio Terhadap Earning Per Share pada PT Indosat Tbk Periode 2008-2019".

\section{TINJAUAN PUSTAKA}

Menurut (Kasmir 2012:201) Return On assets adalah rasio yang menunjukkan hasil (return) atau jumlah aktiva yang digunakan dalam perusahaan dengan kata lain semakin tinggi rasio ini maka semakin baik produktivitas asset dalam memperoleh keuntungan bersih. Hal ini selanjutya akan meningkatkan daya tarik prusahaan kepada investor, kana tingkat pengembalian atau dividen akan semakin besar.Pengertian ROA (Return On Assets) menurut Rivai,dkk (2013:480) adalah kemampuan perusahaan dalam memanfaatkan aktivanya untuk memperoleh laba..

Dari pengertian diatas dapat disimpulkan bahwa ROA adalah rasio yang menunjukkan seberapa banyak laba bersih yang bisa diperoleh oleh seluruh kekayaan yang dimiliki perusahaan. Dengan demikian rasio ini menghubungkan keuntungan yang diperoleh dari kegiatan perusahaan dengan jumlah investasi atau aktiva yang digunakan unuk menghasilkan keuntungan kegiatan tersebut 
Menurut Fahmi (2012:128), Debt To Equity rasio adalah ukuran yang dipakai dalam menganalisis laporan keuangan untuk mmperlihatkan besarnya jaminan yang tersedia untuk kreditor. dalam hal ini DER berpengaruh signifikan terhadap Eaning Per Share karena perusahaan sudah mampu untuk mengefektifkan dalam menghasilkan kuntungan diperiode yang akan datang. Secara tidak langsung jika keuntungan perusahaan besar,maka EPS yang dibagikan juga meningkat, "Jika suatu perusahaan menanggung beban utangyang tinggi, yaitu melebihi modal sendiriyang dimiliki, maka harga sahamperusahaan akan menurun" (Devi danSudjarni, 2012:3).

Dari pengertian diatas dapat disimpukan bahwa debt to aquity rasio adalah rasio keuangan utama dan digunakan untuk menilai posisi keuangan suatu perusahaan.

Earning Per Share atau disebut juga rasio nilai buku, merupakan rasio untuk mengukur keberhasilan manajemen dalam mencapai keuntungan bagi pemegang saham (Kasmir, 2016:205). Alasan menggunakan Earning Per Share (EPS) dalam penelitian ini karena EPS menunjukkan besarnya laba bersih perusahaan yang akan dibagikan untuk semua pemegang saham perusahaan dan memberikan informasi kepada para pihak luar (ekstern) seberapa jauh kemampuan perusahaan menghasilkan laba untuk tiap lembar saham yang beredar.

Dari pengertian diatas dapat disimpulkan EPS adalah rasio keuangan yang mengukur jumlah laba bersih yang diperoleh per lembar saham yang beredar.

\section{METODE}

Penelitian ini dilakukan pada PT Indosat Tbk, penelitian ini diselesaikan selama kurun waktu lima bulan terhitung dari periode Juni sampai Oktober 2020.

Dalam penelitian ini terdapat dua variabel utama atau Independen, yaitu : Return On Asset dan Debt To Equity Ratio Terhadap Earning Per Share yang diberikan perusahaan pada periode tertentu. Dan
Variabel Dependen atau variabel Tergantung yaitu Earning Per Share.

\section{PEMBAHASAN}

Berdasarkan hasil perhitungan $t$ dapat diketahui bahwa thitung sebesar 29.371 dan nilai signifikan sebesar 0.000 atau lebih kecil dari nilai signifikan 0.05 (5\%), kemudian nilai ttabel 1.833 lebih kecil dari thitung (29.371 > 1.833) dengan demikian dapat disimpulkan bahwa Ho ditolak Ha diterima yang berarti return on asset secara parsial berpengaruh dan signifikan terhadap earning per share. Dapat disimpulkan bahwa penelitian ini sejalan dengan penelitian Saiful Anwar (2017) dengan judul Analisis pengaruh DER, ROA, CR, TATO, dan PER Terhadap EPS Pada perusahaan manufaktur Sektor Barang Konsumsi yang terdaftar di BEI periode 2013-2015. Hasil penelitian menunjukkan bahwa secara parsial "return on asset berpengaruh terhadap earning per share".

Berdasarkan hasil perhitungan uji $\mathrm{t}$ diketahui bahwa nilai $\mathrm{t}$ tidak signifikan sebesar 0.100 atau lebih besar dari 0.05 (5\%). Kemudian dari nilai thitung 1.834 dan ttabel 1.833 (thitung > ttabel) dengan demikian dapat disimpulkan bahwa Ho diterima $\mathrm{Ha}$ ditolak, yang artinya debt to equity ratio tidak berpengaruh signifikan terhadap earning per share. Yang berarti DER tidak dapat digunakan untuk memprediksi perubahan Earning Per Share. Hasil penelitian ini sejalan dengan penelitian Herbirowo Nugroho, Taufik Ichsan (Juni 2011) dengan judul Pengaruh ROA dan DER terhadap EPS, Study Kasus pada Kelompok Industri Farmasi yang Terdaftar Di Bursa Efek Indonesia Periode 2004-2009. Hasil nya menunjukkan bahwa secara parsial DER tidak berpengaruh terhadap EPS.

Berdasarkan hasil perhitungan uji $\mathrm{F}$ diketahui Fhitung memiliki nilai 448.783 sedangkan Ftabel memiliki nilai 4.100, atau Fhitung > Ftabel $(448.783>4.100)$

dengan nilai signifikan sebesar 0.000 . Maka demikian dapat disimpulkan bahwa Ho ditolak Ha diterima yang artinya return 
on asset dan debt to equity ratio berpengaruh simultan dan signifikan terhadap earning per share. Jadi semua sumbangan yang diberikan oleh variabel independen terhadap variabel dependen diterima dilihat dari nilai Adjusted RSquare sebesar $98,8 \%$ dan sisanya $1,2 \%$ dijelaskan oleh variabel lain seperti (dividend payout ratio, return on asset, current ratio, maupun faktor pasar dan ekonomi makro seperti kondisi kebijakan pemerintah, inflasi, suku bunga dan lainlain).

\section{KESIMPULAN}

Berdasarkan pengujian regresi yang telah dilakukan, dapat ditarik kesimpulan bahwa, Return On Asset secara parsial berpengaruh dan signifikan terhadap Earning Per Share pada PT Indosat Tbk Tahun 2008-2019 Return On Asset PT Indosat menunjukkan hasil return on asset positif yang artinya ada hubungan searah antara Return On Asset dengan Earning Per Share.

Debt To Equity Ratio secara parsial tidak berpengaruh terhadap Earning Per Share pada PT Indosat Tbk.

Return On Asset dan Debt To Equity Ratio secara simultan atau bersama-sama berpengaruh dan signifikan terhadap Earning Per Share.

\section{DAFTAR PUSTAKA}

Amelia, R. W., \& Sunarsi, D. (2020). Pengaruh Return On Asset Dan Return On Equity Terhadap Debt To Equity Ratio Pada PT. Kalbe Farma, TBK. Ad Deenar: Jurnal Ekonomi dan Bisnis Islam, 4(01), 105-114.

Fahmi, Irham. Analisis Kinerja Keuangan. Bandung: Alfabeta, 2016.

Ghozali, Imam. Aplikasi Analisis Multivariete Dengan Program IBM SPSS 23 (Edisi 8) Cetakan ke VIII.
Semarang: Badan Penerbit Universita Diponegoro, 2012.

Hasibuan, Melayu S.P,. Manajemen Sumber Daya Manusia. Jakarta: PT. Bumi Askara, 2016.

Horne, James C. Van John M wachowich. Prinsip-Prinsip Manajemen Keuangan (Edisi 13). Jakarta: Salemba Empat, 2012.

Ikatan Akutansi Indonesia. Standa Laporan Keuangan Jakarta: Selemba Empat, 2012.

Kasmir. Analisi Laporan Keuangan. Jakarta: Rajawali Pers, 2015.

Margaretha. Dasar-Dasar Manajemen Keuangan . Jakarta: Dian Rakyat, 2014.

Munawir,H.S,. Analisis Laporan Keuangan, Edisi Keempat Yogyakarta: Liberty, 2014.

Rivai, Veithzal Dkk. Commercial Bank Management: Manajemen Perbankan Dari Teori Ke Praktik, Edisi 1, Cetakan 1. Jakarta: Rajawali Pers, 2013.

Siswandi. Pengantar Manajemen. Jakarta: Bumi Aksara, 2011.

Sugiyono. Metode Penelitian Kuantitatif Kualitatif R\&D. Bandung: CV Alfabeta, 2017.

Susanti, N., Latifa, I., \& Sunarsi, D. (2020). The Effects of Profitability, Leverage, and Liquidity on Financial Distress on Retail Companies Listed on Indonesian Stock Exchange. Jurnal Ilmiah Ilmu Administrasi Publik, 10(1), 45-52.

Usman, Dalam Spare. Manajemen. Jakarta: Erlangga, 2013.

Wahyudiono, Bambang. Mudah Menbaca Laporan Keuangan. Jakarta: Raih Asa Sukses (Penebar Swadaya Grup), 2014.

Wibowo. Manajemen Kinerja. Jakarta: PT. raja Grafindo Persada, 2012. 